\title{
É POSSÍVEL FAZER CIÊNCIA DE QUALIDADE NA EDUCAÇÃO BÁSICA! EM EVIDÊNCIA, O MARANHÃO
}

\author{
Marcos Eduardo Miranda Santos ${ }^{\mathrm{a}^{*}}$ \\ ${ }^{a}$ Supervisão dos Centros de Educação em Tempo Integral. Secretaria de Estado da Educação. Rua das Figueiras, 101 - \\ Jardim Sao Francisco, São Luís, MA, Brasil. \\ * Editor-chefe.
}

\section{Caros leitores/as.}

Com muita alegria publicamos a $1^{\mathrm{a}}$ edição da Revista Pesquisa e Inovação na Escola, o primeiro periódico científico da Secretaria de Estado da Educação do Maranhão (SEDUC), e um dos poucos periódicos voltados para a divulgação de pesquisas realizadas na e pela Educação Básica ao nível nacional.

A educação brasileira vive um período de mudanças, tanto no âmbito pedagógico, quanto no âmbito financeiro e estrutural, as quais, assim como quaisquer outras, trarão ônus e bônus que apenas o tempo revelará. Em paralelo, a Ciência, Tecnologia e Inovação também passa por mudanças no cenário nacional. No caso, mudanças, preponderantemente (porém não exclusivamente), de caráter financeiro. Cortes em recursos para pesquisa e inovação, e a consequente desvalorização dos/as pesquisadores/as brasileiros/as tem assutado e desestimulado a comunidade acadêmica.

Não bastassem esses assustadores cenários pairando sobre a Educação e Ciência, percebe-se o avanço de movimentos anticiência, baseados em fundamentalismos e ideologias partidárias; que em parte, são frutos da dificuldade e negligência dos cientistas em comunicar, e, porque não dizer devolver, à sociedade os resultados de suas pesquisas de forma acessível ao público leigo.

A despeito destes cenários, o Governador do Estado do Maranhão, Flávio Dino, por meio da Secretaria de Estado da Educação, gerida pelo Secretário Felipe Camarão, tem feito investimentos substanciais em Educação, Ciência e Tecnologia. Ambos são cientes e sensíveis da necessidade de fortalecer este tripé para garantir a cidadania e qualidade de vida à população maranhense. Ademais, entendem que a única forma de combater o negacionismo é através de uma educação de qualidade alinhada ao pensamento científico.

Através da Supervisão dos Centros de Educação em Tempo Integral (SUPCETI),

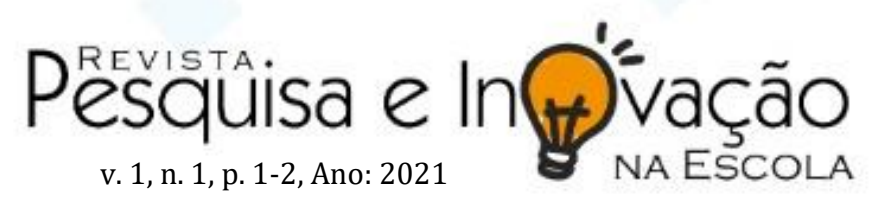


vinculada à Secretaria Adjunta de Educação Profissional e Integral (SAEPI), capitaneada pelo Secretário Adjunto André Bello, a SEDUC tem promovido Educação Cientifica e fomentado o ensino pela pesquisa no ambiente escolar. Os Centros Educa Mais, a maior rede de Educação em Tempo Integral do Maranhão, se destaca por valorizar a investigação cientifica como mote para formação de profissionais qualificados, éticos e solidários. Isso é bem visível, tendo em vista os excelentes indicadores da rede refletidos nas premiações obtidas ao nível nacional e produções científicas de qualidade promovidas pelas comunidades escolares.

Nesta $1^{a}$ edição, apresentamos seis artigos originais e uma nota técnica resultantes de pesquisas desenvolvidas por estudantes e professores da rede de ensino integral do Maranhão. Entre pesquisas aplicadas e de caráter bibliográfico, os 'papers' apresentados dialogam com diferentes objetos que estão na interface da Ciência e Sociedade. São apresentados relatos de pesquisas orientadas por docente, que por meio da Pedagogia Ativa e de outras metodologias inovadoras, ressignificaram sua prática pedagógica e colaboraram para a definição do projeto de vida de seus orientandos.

Temas como Educação em Ciências, Robótica Educacional, Impactos Ambientais, Tecnologias para Educação, Práticas de Ensino e Perspectivas para o Ensino Superior são ricamente explorados pelos autores que, fundamentados na literatura científica mais atual, a corroboram e complementam. Por fim, desejamos a todos/as uma leitura prazerosa e que amplie o horizonte de seus conhecimentos. Desde já, deixamos o convite aos/as interessados/as a submeterem seus manuscritos à $2^{\mathrm{a}}$ edição de nossa revista e assim divulgar as boas práticas pedagógicas e científicas realizadas nas escolas públicas á comunidade científica brasileira.

Boa leitura!

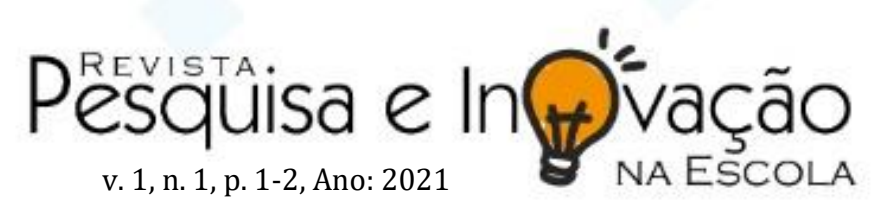

